J. Product. \& Dev., 21(3): 255- 274 (2016)

\title{
RESPONSE OF ZEBDA MANGO TREES TO ORGANIC AND BIO NITROGEN FERTILIZATION AS A PARTIAL SUBSTITUTE FOR MINERAL NITROGEN
}

\section{S.I. Habashy}

Tropical Fruit Research Department, Hort. Res. Inst. Agric. Res. Center,

Giza, Egypt.

\begin{abstract}
The present study was executed in 2014 and 2015 seasons on 23-yearold Zebda mango trees grown in sandy soil under drip irrigation system at the experimental orchard of El-Kassasien Hort. Res. Station, Ismailia Governorate. This investigation aimed to study the possibility of using the organic nitrogen (chicken manure $3.21 \%$ N) with bio nitrogen (biogen) fertilizers partially instead of completed mineral nitrogen (ammonium sulphate $20.6 \% \mathrm{~N}$ ).

Results revealed that reducing the percentage of mineral nitrogen from $100 \%$ to $25 \%$ and increasing organic nitrogen to $75 \%$ with biofertilizers ( $100 \mathrm{~g}$ biogen /tree) had an announced promotion and increasing number and length of new shoots, number of leaves/ shoot , leaf area, N,P and $K$ contents, number of initial and retention fruit set percentage and yield ( $\mathrm{kg} /$ tree). Fruit weight and pulp firmness, TSS and vitamin $C$ content were also increased. While, fruit peel thickness and juice acidity percentage were significantly decreased in comparison with the control treatment (100\% mineral $N)$.

Conclusively, under the conditions of this study, $75 \%$ of organic nitrogen (23.36 kg chicken manure/tree) $+25 \%$ mineral nitrogen (1.21 $\mathrm{kg}$ ammonium sulphate/tree) with biogen bio-fertilizer at $100 \mathrm{~g} /$ tree was sufficient for minimizing mineral nitrogen fertilization to the quarter and increasing yield/tree by $41.50 \%$ (average of the two seasons) with the best fruit quality of Zebda mango as compared with control treatment.
\end{abstract}

Key words : Zebda mango, ammonium sulphate, chicken manure, biogen, yield and fruit quality.

\section{INTRODUCTION}

Mango (Mangifera indica L.) is one of the important fruit crops in tropical zones of the world and Egypt. In Egypt, it considered the most popular fruit crop and occupies the second rank place in area after citrus. 
The total acreage of mango reached about 240804 fed.; out of them 183341 fed. are fruit full producing about 786528 tons with an average of 4.28 tons/fed. according to Ministry of Agric. statistics, 2012. Common problems face and affect mango productivity are poor fruit set and high fruit drop percentages at different fruit growth stages in addition to alternate bearing habit.

The nitrogen fertilization is an important factor for growth and productivity of mango trees, specially Zebda cv.

Application of organic manure has numerous merits such as reducing soil $\mathrm{pH}$ and salinity and increasing the availability of all nutrients, as well as enhancing soil organic matter, cation exchange capacity and fertility in addition to biological activity, formation of natural hormones, antibiotics , vitamins B and developments of roots (Nijjar, 1985; Russo and Berlyn, 1990 and Dahama, 1999).

Biofertilization are benefit in enhancing biological activity due to its higher own from microorganisms. It is responsible in suppresses plant pathogens and diseases, conservation of energy in plants, solublization of minerals in the soil and promotion of photosynthetic efficiency and biological $\mathrm{N}$ fixation (Higa and Wididana, 1991; El-Haddad et al., 1993; Myint , 1999 and Kannaiyan, 2002).

Previous studies emphasized that using the suitable $\mathrm{N}$ form through inorganic , organic and bio fertilization was preferable rather than using mineral $\mathrm{N}$ fertilization alone in enhancing soil fertility, growth, yield and fruit quality of all evergreen fruit crops particularly mangoes, bananas, date palms and citrus ( Moustafa, 2002; Gabara and Ahmed, 2004; Mansour et al., 2004, Mohamed and Ragab, 2004; Roshdy, 2004; El-Assar, 2005, Shaarawy, 2005; Diab, 2006; Mouftah, 2007; Abdo, 2008; Al-Wasfy and ElKhawaga, 2008; El-Salhy, 2008; Mahmoud, 2008, Sayed, 2008; Shaalan, 2008; Morsi , 2009; Shaheen et al., 2009; Ibrahim, 2010; Mahfouz , 2011; Saad et al., 2011; Abdelaal et al., 2012; El-Khawaga, 2012; Ibrahim, 2012; Mahmoud, 2012; Farag, 2013 and Al-Wasfy and Abd El-Rahman, 2014).

Therefore, the objective of this study was examining the effect of replacing mineral $\mathrm{N}$ fertilizer partially using chicken manure as an organic $\mathrm{N}$ fertilizer and biogen as bio-N fertilizer on fruit set, yield and fruit quality of Zebda mango trees grown in sandy soil.

\section{MATERIALS AND METHODS}

The present investigation was carried out during the three consecutive seasons of 2013, 2014 and 2015 (the first season considered as 
a preliminary trail) on 23 -year -old Zebda mango trees ( Mangifera indica L.) grafted on seedling rootstock. The trees were planted at $7 \mathrm{~m}$ apart in sandy soil and drip irrigated using a moderate saline irrigation water (780 ppm) in the experimental orchard of El-Kassasien Hort. Research Station, Ismailia Governorate.

At the beginning of this investigation 21 trees were selected for nearly similar size and being in their off-bearing year in the previous season. The experimental trees were healthy and uniform in vigor, shape and free from bests infestation. The orchard soil analyses are given in Table (A) according to Wilde et al. (1985).

Table (A). Some physical and chemical analysis of the orchard soil

\begin{tabular}{|l|c|l|c|}
\hline \multirow{2}{*}{ Physical properties } & $(\%)$ & \multicolumn{1}{|c|}{ Chemical properties } & Value \\
\hline Field capacity & 11.77 & $\mathrm{CaCO}_{3}(\%)$ & 12.25 \\
\hline Available water & 1.55 & Organic matter $(\%)$ & 0.48 \\
\hline Wilting point & 4.20 & $\mathrm{pH}(1: 2.5$ extract $)$ & 7.75 \\
\hline Coarse sand & 67.80 & $\mathrm{E} . \mathrm{C} .(1: 2.5$ extract, $\mathrm{mhos} / 1 \mathrm{~cm})$ & 1.21 \\
\hline Fine sand & 19.00 & $\mathrm{~N}(\mathrm{mg} / \mathrm{kg})$ & 84.00 \\
\hline Silt & 8.00 & $\mathrm{P}(\mathrm{mg} / \mathrm{kg})$ & 8.00 \\
\hline Clay & 5.20 & $\mathrm{~K}(\mathrm{mg} / \mathrm{kg})$ & 117.00 \\
\hline Texture grade & Sandy & & \\
\hline
\end{tabular}

The treatments were arranged in a randomized complete design, the experiment includes seven treatments, each contains three replicates and the replicate represented by one tree. The normal agriculture practices that used in the orchard were applied to all experimental trees, except those dealing with nitrogen fertilization. Mango tree require $1000 \mathrm{~g}$ actual nitrogen yearly according to the recommendations of Ministry of Agriculture, Egypt. The recommended rate of $\mathrm{N}$ was applied through three sources of $\mathrm{N}$ as follows:

(1) Mineral source of $\mathrm{N}$ namely ammonium sulphate $(20.6 \% \mathrm{~N})$ which was applied at fourteen equal doses weekly starting at the third week of Feb. and through March, May and June (Mansour and Shaaban, 2007) found that, the best source of mineral $\mathrm{N}$ applied with organic and bio biofertilizers were ammonium sulpahte).

(2) Organic source of $\mathrm{N}$ namely chicken manure $(3.21 \% \mathrm{~N})$ was added once in a circle around each tree at the second week of Jan., then covered with the soil and irrigated (Fayed, 2010 indicated that chicken manure as a rule the best and foregoing of the organic fertilizers). 
(3) Biogen as a bio- fertilizer contain Azotobacter and Azospirillum bacteria $\mathrm{N}$ fixing bacteria was applied at same place of potting chicken manure at the first week of Feb. with constant rate $100 \mathrm{~g}$ /tree, then covered with the soil and irrigated.

Table (B).

The chemical composition of the tested chicken manure are shown in

Table (B). Some chemical characteristics of the chicken manure

\begin{tabular}{|l|c|}
\hline Parameters & Values \\
\hline Cubic meter ( kg) & 535.0 \\
\hline Moisture (\%) & 12.52 \\
\hline Organic matter (\%) & 52.78 \\
\hline Organic carbon (\%) & 34.70 \\
\hline $\mathrm{pH}$ & 7.12 \\
\hline $\mathrm{C} / \mathrm{N}$ ratio & 10.80 \\
\hline Total N (\%) & 3.21 \\
\hline Total P (\%) & 0.65 \\
\hline Total K (\%) & 1.19 \\
\hline
\end{tabular}

The seven $\mathrm{N}$ fertilization treatments involved in this study was arranged as follows:

$\mathrm{T}_{1}-100 \%$ mineral nitrogen fertilization $(1000 \mathrm{~g} \mathrm{~N} / \text { tree })^{*}$ via ammonium sulphate $(4.85 \mathrm{~kg} /$ tree $)$ as a control.

$\mathrm{T}_{2}-100 \%$ organic fertilization via chicken manure $(31.15 \mathrm{~kg} / \mathrm{tree})$.

$\mathrm{T}_{3}-100 \%$ organic via chicken manure $(31.15 \mathrm{~kg} / \mathrm{tree})$ with bio-nitrogen fertilization via biogen $(100 \mathrm{~g} /$ tree $)$.

$\mathrm{T}_{4}-75 \%$ organic via chicken manure $(23.36 \mathrm{~kg} /$ tree $)+25 \%$ mineral via ammonium sulphate $(1.21 \mathrm{~kg} /$ tree $)$.

$\mathrm{T}_{5}-75 \%$ organic via chicken manure $(23.36 \mathrm{~kg} /$ tree $)+25 \%$ mineral via ammonium sulphate $(1.21 \mathrm{~kg} / \mathrm{tree})$ with biogen $(100 \mathrm{~g} / \mathrm{tree})$.

$\mathrm{T}_{6}-50 \%$ organic via chicken manure $(15.58 \mathrm{~kg} /$ tree $)+50 \%$ mineral via ammonium sulphate $(2.43 \mathrm{~kg} / \mathrm{tree})$.

$\mathrm{T}_{7}-50 \%$ organic via chicken manure $(15.58 \mathrm{~kg} /$ tree $)+50 \%$ mineral via ammonium sulphate $(2.43 \mathrm{~kg} /$ tree $)$ with biogen $(100 \mathrm{~g} /$ tree $)$.

* Those treatments represents the recommended rate of actual nitrogen of tree.

The following parameters were recorded:-

\section{Vegetative characteristics:}

At the beginning of each growth season ( early March ) one -yearold nine vegetative branches, were randomly chosen and marked on each 
tree to determine the number of newly formed shoots per twig, length $(\mathrm{cm})$ and number of leaves per shoot at the end of each season ( late of Sept.). The average leaf area $\left(\mathrm{cm}^{2}\right)$ was estimated on five mature leaves for each replicate detached from the medium portion of the tagged shoots starting from the third leaf using a Ci-203 area meter CID, Inc ( USA).

\section{Leaf macro elements contents}

Leaf samples were taken in October from the middle position of current season shoots. The leaves were cleaned then dried at $70{ }^{\circ} \mathrm{C}$ and digested with sulphuric and perchloric acids $(3: 1 \mathrm{v} / \mathrm{v})$. The leaf nitrogen content was determined according to the micro Kjeldahl method as described by Black (1965), phosphorus was determined spectrophotometrically as described by John (1970) and potassium content was flamephotometrically determined according to the method of Jackson (1965). The leaf NPK contents were expressed as percentage on dry weight basis.

\section{Fruiting parameters:}

At full bloom 40 panicles / tree distributed at the four directions were of each tree chosen at random and tagged. The following parameters were determined: Number of initial fruit set / panicle (15 days after petal fall), number of retained fruits/panicle (at harvest ) and percentage of retained fruits at harvest (percentage of retained fruits $=$ average number of retained fruits per panicle at harvest / average number of initial fruit set per panicle $\mathrm{x} 100)$.

Harvest was achieved during the regular commercial harvest time under Ismailia Governorate conditions (mid of August) in both seasons when the flesh of fruits become yellowish.

Yield/ tree (kg): Yield / tree was estimated at harvest by multiplying the number of fruits born on each tree $\mathbf{x}$ average fruit weight.

\section{Fruit quality:}

Samples of five mature fruits per tree were randomly chosen and kept in the laboratory till ripe stage. The following fruit quality parameters were assessed : Fruit weight (g), peel thickness $(\mathrm{mm})$ by a vernier caliper, flesh firmness $\left(\mathrm{Lb} / \mathrm{inch}^{2}\right)$ using penetrometer (pressure tester), juice total soluble solids TSS (Brix) using an Abb. digital refractometer, juice total acidity percentage as citric acid was measured according to (A.O.A.C., 1995) and vitamin $\mathrm{C}$ content was determined by titration with dichlorophanol indophenol blue dye (expressed as $\mathrm{mg} / 100 \mathrm{ml}$ juice). 


\section{Statistical analysis:}

The obtained data were tabulated and statistically analyzed according to Snedecor and Cochran (1991) and means separation was done according to Duncan (1955) at 0.05 levels of probability.

\section{RESULTS AND DISCUSSION}

\section{Vegetative characteristics:}

Results in Table (1) illustrate that vegetative growth parameters , i.e., number of new shoots per twig, shoots length, number of leaves per shoot and leaf area were significantly affected by the applied fertilizers treatments in both seasons of study.

It was found that Zebda mango trees receiving $75 \%$ organic nitrogen $(\mathrm{ON})+25 \%$ mineral nitrogen $(\mathrm{MN})$ with bio nitrogen $(\mathrm{BN})$ recorded the highest values of these parameters, followed in a descendingly order by $50 \%$ $\mathrm{ON}+50 \% \mathrm{MN}$ with $\mathrm{BN}$ and $100 \% \mathrm{ON}$ with $\mathrm{BN}$ treatments, respectively. The least values were gained by control, treatment other treatments were in between range. The positive effects of organic manure on the vegetative characteristics could be attributed to their effects on supplying the trees with their requirements of various nutrients as a relatively long times, as well as, their effect on lowering soil $\mathrm{pH}$ which could aid in facilitating the availability of some nutrients in the soil and improving physical characters of the soil in favor of root development (Gamal and Ragab, 2003). However, Abou El-Khashab, (2002) reported that, the enhancement of plant growth due to inoculation with $\mathrm{N}$-fixing bacteria could be attributed to the capability of these organisms to produce growth regulators such as auxine, cytokinins and gibberellins which affect production of root biomass and nutrients uptake.

These results are in agreement with those reported by El-Morshedy (1997) on sour orange, Abdel El-Naby and Gomaa, (2000) on banana, Maksoud, (2000) on olive, Helial et al. (2003) on Washington navel orange trees, Abde EL-Naby and El-Sonbaty (2005) on banana, Hegazi et al. (2007) on picual olive trees and Osman and Abd El-Rhman (2010) on fig trees.

\section{Leaf N, $P$ and $K$ contents:}

Data in Table (2) indicate that leaf nitrogen $(\mathrm{N})$, phosphorus $(\mathrm{P})$ and potassium $(\mathrm{K})$ contents were significantly affected by different tested treatments during the two seasons. The highest percentages of $\mathrm{N}, \mathrm{P}$ and $\mathrm{K}$ were gained by $75 \% \mathrm{ON}+25 \% \mathrm{MN}$ with $\mathrm{BN}$ without significant differences between $50 \% \mathrm{ON}+50 \% \mathrm{MN}$ with $\mathrm{BN}$ and $100 \% \mathrm{ON}$ with $\mathrm{BN}$ treatments concerning $\mathrm{N}$ and $\mathrm{K}$ in both seasons. While $100 \% \mathrm{MN}$ (control) and other 
treatments recorded the least percentages without significant differences between them except few cases in both seasons.

The outstanding role of organic fertilization on reducing the loss of nutrients through drainage water could explain the present results. Similar findings were reported by Nijjar (1985), El-Hady et al. (1991), El-Sayed (1994), Kassem and Marzouk (2002), Lopez-Granados et al. (2004), Hegazi et al. (2007), Morsi (2009) and Shaheen et al.(2013) who found that adding organic manure increased leaf minerals content due to availability of nutrients in the soil, resulting in more available nutrients to plant uptake. However, ElKramany et al. (2000) found that, bio-fertilizers help in availability of minerals and their forms in the composted material and increased levels of extractable $\mathrm{N}, \mathrm{P}$ and $\mathrm{K}$.

It is clear from Table (3) that the number of initial fruit set per panicle reached its highest values due to applying $75 \% \mathrm{ON}+25 \% \mathrm{MN}$ with $\mathrm{BN}$ followed by $50 \% \mathrm{ON}+50 \% \mathrm{MN}$ with $\mathrm{BN}$ and $100 \% \mathrm{ON}$ with $\mathrm{BN}$ treatments in descendingly order. The lowest values were recorded by $100 \%$ $\mathrm{MN}$ (control), the other treatments gained intermediate values in both experimental seasons.

As shown in Table (3) the retained fruits at harvest, fruit retention percentage and yield $(\mathrm{kg} / \mathrm{tree})$ of Zebda mango fruits were significantly affected by the tested $\mathrm{N}$ treatments during both seasons. The highest values of all parameters were recorded by application $75 \% \mathrm{ON}+25 \% \mathrm{MN}$ with $\mathrm{BN}$ treatment followed by the other treatments with significant differences between them. The lowest values were achieved by $100 \% \mathrm{MN}$ (control) in both seasons. Fruit yield (kg/tree) was increased in the second season than in the first one, mainly due to accumulation effects of organic fertilization treatments.

The relative increases in fruit yield /tree was about (39.68 and $43.33 \%$ ) due to the application of $75 \% \mathrm{ON}+25 \% \mathrm{MN}$ with $\mathrm{BN}$ as compared with control treatment both seasons, respectively.

These results are in agreement with those obtained by Abou-ElKhashab et al. (2005), Fayed (2005), El-Rawy (2007), Hegazi et al. (2007), Mostafa (2008), Mohammed et al. (2010), Uwakiem (2011) and Shaheen et al. (2013).

\section{Fruit physical properties:}

As shown in Table (4) all of the conducted treatments significantly increased the average fruit weight and pulp firmness compared with control one in both seasons. The heaviest fruit weight was recorded for $75 \% \mathrm{ON}$ $+25 \% \mathrm{MN}$ with $\mathrm{BN}$ treatment as compared with the other treatments with 
significant differences between them in the two seasons. These findings are in harmony with those obtained by Fouad et al., (2002), Sharawy (2005) and Osman and Abd El-Rhman (2010) for fruit weight and Alaa El-Din and El Sayed (2007) concerning mango fruit pulp firmness.

Fruit peel thickness was affected by the conducted treatments. The thickset peel was recorded for fruits of control treatment $(100 \% \mathrm{MN})$ in the first and second seasons. It is noticed that, treatments included organic and bio-fertilizers tended to decrease peel thickness. These results confirmed those of Abd El-Migeed et al. (2007).

\section{Fruit chemical characteristics:}

It is apparent from Table (5) that fruit chemical properties, i.e., total soluble solids, titratable acidity, TSS/acid ratio and vitamin $\mathrm{C}$ content were significantly affected by $\mathrm{N}$ fertilization treatments in the two seasons of this study. The highest percentages of total soluble solids and TSS/acid ratio and the lowest acidity percentage were found in fruits of trees receiving $75 \% \mathrm{ON}+25 \% \mathrm{MN}$ with $\mathrm{BN}$ compared with $100 \% \mathrm{MN}$ treatment ( control) in both seasons. The other treatments gained intermediate percentage with significant differences between them. These results are in accordance with those reported by El-Sawy (2005); Alaa-ElDin and El-Sayed (2007); Mouftah (2007); Ahmed et al. (2011) and El-Khawaga (2012).

Regarding vitamin $\mathrm{C}$ content, results show significant differences in both seasons of study. The superiority was recorded for $75 \% \mathrm{ON}+25 \%$ $\mathrm{MN}$ with $\mathrm{BN}$ treatment with significant differences with the other treatments. Meanwhile the lowest content was gained through applying $100 \% \mathrm{MN}$ treatment (control) in the two seasons. Similar results were reported by Moustafa (2002), Salama (2002); Abd El-Migeed et al., (2007) and Alaa-El-Din and El-Sayed (2007).

Conclusively the gradual increase of organic nitrogen doses with decreasing the dose of mineral nitrogen gave the highest significant increase of TSS, TSS/acid ratio and the lowest total acidity percentage of Thompson Seedless (Belal, 2006). Also, El-Naggar (2004) showed that biofertilizers is favorable in improving nutritional status of the vines, yield , physical and chemical properties of grapevines. El-Rawy (2007) stated that replacing 50-75 \% of $\mathrm{N}$ requirements for grapevine fruits by organic manures improved berry quality.

The promoting effect of organic and biofertilization on fruit quality was attributed mainly to their essential role in enhancing organic foods 
especially total carbohydrates and plant pigments which is reflected on advancing fruit maturity (Nijjar, 1985).

Conclusively, under the conditions of this study, $75 \%$ of organic nitrogen $(23.36 \mathrm{~kg}$ chicken manure/tree $)+25 \%$ mineral nitrogen $(1.21 \mathrm{~kg}$ ammonium sulphate / tree) with biogen bio-fertilizer at $100 \mathrm{~g} /$ tree was sufficient for minimizing mineral nitrogen fertilization to the quarter and increasing yield/tree by $41.50 \%$ (average of the two seasons) with the best fruit quality of Zebda mango as compared with control treatment.

\section{REFERENCES}

Abd El-Migeed, M.M.; M.S. Saleh and E.A. Mostafa (2007). The beneficial effect of minimizing mineral nitrogen fertilization on Washington navel orange trees by using organic and biofertilizerfertilizers. World J. of Agric. Sci.,3 (1): 80-85.

Abdelaal; A.M.; F.F. Ahmed and K.M. Hassan (2012). Partial replacement of chemical $\mathrm{N}$ fertilizers in Balady mandarin orchard through application of extracts of yeast, seaweed and farmyard manure. Minia J. of Agric. Res. \& Develop., 32(1): 129- 148.

Abd El-Naby, S.K. and A.M. Gomaa (2000). Growth nutritional status, yield and fruit quality of Maghrabi banana as affected by some organic manures and biofertilizers. Minufiya J. Agric. Res., 25(4): 1113-1129.

Abd El-Naby, S.K. and M.R. El-Sonbaty (2005). Effect of partial replacement of chemical fertilizers by organic manures in banana production and fruit quality. Assiut J. Agric. Sci., 36: 107-122.

Abdo, Z.A. (2008). Effect of some biofertilization treatments on growth and fruiting of Balady mandarin trees. Ph. D. Thesis, Fac. of Agric., Minia. Univ., Egypt.

Abou El-Khashab, A.M. (2002). Growth and chemical constituents of some olive cultivars as affected by biofertilizers and different water regimes. Egypt. J. Agric. Res., NRC. 1: 243-265.

Abou El-Khashab, A.M.; S.A. Abou Taleb and T.S. Wafaa (2005). Aggezi and Koroneki olive trees as affected by organic and biofertilizers, calcium citrate and potassium. Arab Univ. J. Agric. Sci., Ain Shams Univ., 13: 419-440.

Ahmed, F.F.; A. A. Ibrahiem; A.E. Mansour; E.A. Shaaban and M.S. El- Shamaa (2011). Response of Thompson Seedless grapevines to application of some amino acids enriched with nutrients as well as organic and biofertilization. Res. J. Agric. \& Biol. Sci., 7(2): 282-286. 
Alaa El-Din, Kh. O. and B.B. El-Sayed (2007). Effect of organic, inorganic and bio- fertilizer application on yield and fruit quality of mango trees cv. Sukari. J. Agric. Res., Kafer El-Sheikh Univ., 33 (4): 857-872.

Al- Wasfy, M.M. and A.S. El- Khawaga (2008). Effect of organic fertilization on growth, yield and fruit quality of Zaghloul date palms grown in sandy soil. Assiut J. of Agric. Sci., 39(1): 121- 133.

Al-Wasfy, M.M. and M.M. Abd El- Rahman (2014). Reducing inorganic $\mathrm{N}$ fertilizer partially in Hayany date palm orchards by using animal and chicken manures. World Rural Observations; 6(1): 94-98.

A.O.A.C. (1995). Association of Official Analytical Chemist's. Official Methods Of Analysis, $16^{\text {th }}$ Ed; Virginia, U.S.A.

Belal, E.A. (2006). Effect of some kinds of fertilizers on yield and quality of Thompson Seedless grapevines (Vitis vinifera L.). Ph.D. Thesis, Fac. of Agric., Mansoura Univ., Egypt.

Black, C. A. (1965). Method of Soil Analysis, Part 2, Chemical and Microbiological Properties, American Society of Agronomy, Inc, Publisher, Madison, Wisconsin USA.

Dahama A.K. (1999). Organic Farming; For Sustainable Agriculture. Agro Botanic, Daryagun, New Delhi, India , pp:258.

Diab, Y.M. (2006). Effect of some cultural practices on yield and fruit quality of Phonix dactylifera L. $c v$ Sewy under New Valley conditions M. Sc. Thesis Fac. of Agric. Assiut Univ. Egypt.

Duncan, D.B.(1955). Multiple range and multiple test. Biometrics, 11: 1-24.

El- Assar A.M. (2005). Response of Zaghloul date yield and fruit characteristics to various organic and inorganic fertilization types as well as fruit thinning models in a rich carbonate soil. J. Agric. Sci. Mansoura Univ., 30 (5): 2795-2814.

El- Haddad, M.E.; Y.Z. Ishac and M.L. Mostafa (1993). The role of biofertilizers in reducing agricultural costs, decreasing environmental pollution and raising crop yield. Arab Univ. J. Agric. Sci., Ain Shams Univ., Cairo, 1(1): 147-195.

El-Hady, O.A.; A.H. Hanna and M.M. Kattab (1991). Interaction of organic manures and bitumen emulsion on a sandy soil and the growth response on nutrient levels in the olive leaves. Egypt. J. Soil Sci., 31: 65-88.

El- Khawaga A. S. ( 2012). Effect of compost enriched with actinomyces and Bacillus polymyxa Algae as a partial substitute for mineral $\mathrm{N}$ in Ewaise mango orchards. Res. J. Agric. \& Biol. Sci., 8(2): 191-196.

El-Kramany, M.F.; M.K. Ahmed; A.A. Bahr and M.O. Kasber ( 2000). Utilization of bio-fertilization in field crop production. Egypt. J. Appl. Sci., 15: 137-149. 
El- Morshedy, F.A. (1997). Organic manure and sulphur interaction influence vegetative growth and element concentration of sour orange seedlings. J. Agric. Sci., Mansoura Univ., Egypt, 22(12): 4599- 4614.

El-Naggar, A.M. (2004). Effect of organic farming on drip irrigation grapevine and soil chemical properties. Proceeding of the $2^{\text {nd }}$ Inter. Confer. Agric., Nasr City, Cairo, Egypt, pp: 117-128.

El-Rawy, H.A. (2007). Physiological studies on fertilization of King Ruby grapevines. Ph.D. Thesis, Fac. Agric., Assiut University.

El- Salhy A.M. (2008). Effect of mineral and organic nitrogen fertilization on vegetative growth, yield and fruit characteristics of Sewy date palms. 3rd Inter. Conf. For Date Palms Agric., Sci. and Environ. Fac. Suez Canal Univ., El-Arish, 25-27.

El- Sawy, Y.A. (2005). Studies on the effect of some organic fertilizers, ammonium nitrate and the biofertilizer (Algae extract) on growth and productivity of Williams banana (Musa Cavendishii L.). M. Sc. Thesis Fac. of Agric., Minia Univ., Egypt.

El-Sayed, M.A. (1994). The benefits of some organic nitrogen fertilizers on Red Roomy grape vines (Vitis vinifera L.). Minia J. Agric. Res. Dev., 10: $1245-1260$.

Farag M.H. (2013). Reducing the amount of chemical fertilization partially by using organic and biofertilization in Balady mandarin orchards. $\mathrm{M}$. Sc. Thesis Fac. of Agric., Minia Univ., Egypt.

Fayed, T.A. (2005). Effect of some organic manures and biofertilizers on Anna apple trees. 2-Yield and fruit characteristics. Egypt. J. App. Sci., 20(1): 176-191.

Fayed T.A. (2010). Response of four olive cultivars to common organic manures in Libya. American-Eurasian J. Agric. \& Environ. Sci., 8 (3): 275-291.

Fouad, A. H.; F.A. Khalil ; E.M. Mansour and E. A. Shaaban (2002). Studies on the effect of organic nitrogen and /or mineral nitrogen, phosphorus and potassium fertilizers on the yield and fruit quality of Washington navel orange trees. Proc. Minia $1^{\text {st }}$ Conf. for Agric. and Enviro. Sci., Minia, Egypt, Mar. 25-78, 22 (4): 1797-1800.

Gamal, A.M. and M.A. Ragab (2003). Effect of organic manure source and its rate on growth, nutritional status of the trees and productivity of Balady mandarin trees. Assiut J. Agric. Sci., 4: 253-264

Gabara, A.A. and F.F. Ahmed (2004). Response of Zaghloul date palms to application of some biofertilizers. $2^{\text {nd }}$ Ineter. Conf. on date palm Suez Canal Univ. El-Arish, Egypt, 6-8 October (2004). 
Hegazi, E.S.; M.R. El-Sonbaty; M.A. Eissa; and T.F. El-Sharony (2007). Effect of organic and bio-fertilization on vegetative growth and flowering of Picual olive trees. World J. Agric. Sci., 3(2): 210-217.

Helail, B.M.; Y.N. Gobran and M.H. Moustafa (2003). Study on the effect of organic manure source, method of organic manure application and biofertilizers (1): Tree growth and leaf mineral content of Washington navel orange trees. Egypt. J. Appl. Sci., 18: 297-320.

Higa, Y. and G.N. Wididana (1991). Changes in the soil microflora induced by effective microorganisms. Proc. Of the $1^{\text {st }}$ Inter. Conf. of Kyusei Nature Farming, M.S. Dept. of Agric., Washington, D.C., USA, pp. 153-162.

Ibrahim- Z. A. (2010). Fertilization of date palm Amhat cv. grown in new reclaimed land by organic and inorganic nitrogen sources. The sixth Inter. Conf. of Sustain Agric. And Develop. Fac. of Agric. Fayoum Univ., 27-29.

Ibrahim, W.M. (2012). Behaviour of Taimour mango trees to inorganic and organic fertilization and application of EM. Ph. D. Thesis Fac. of Agric. Minia Univ. Egypt.

Jackson, M.L. (1965). Soil Chemical Analysis. Prentice-Hall of India , New Delhi.

John M. K. (1970). Colorimetric determination of phosphorus in soil and plant materials with ascorbic acid. Soil Sci., 109:219·220

Kannaiyan, S. (2002). Biotechnology of Biofertilizers. Alpha Sci. Inter. Ltd., P.O. Box 4067 Pang Bourne R.68, U.K. pp: 1 -275

Kassem, H.A. and H.A. Marzouk (2002). Effect of organic and/or mineral nitrogen fertilization on the nutritional status, yield and fruit quality of Flame Seedless grape vines grown in calcareous soil. J. Adv. Res., 7(3): 117-126.

Lopez-Granados, F.; M. Jurado-Exposito; S. Alamo and L. GaricaTorres (2004). Leaf nutrients spatial variability and site-specific fertilization maps within olive (Olea europaea L.) orchard. Europ. J. Agronomy, 21: 209-222.

Mahfouz, M.S. (2011). Partial replacement of chemical fertilizers by some organic and biofertilizers in Williams banana plants under Minia region conditions. Ph. D. Thesis, Fac. of Agric., Minia Univ., Egypt.

Mahmoud, Kh. M. (2012). Reducing $\mathrm{N}$ fertilizer in Balady mandarin orchard through application of extracts of yeast, seaweed and farmyard manure M. Sc. Thesis, Fac. of Agric., Minia Univ., Egypt.

Mahmoud S.M. (2008). Response of Valencia orange trees to organic and biofertilization. M. Sc. Thesis, Fac. of Agric., Minia Univ., Egypt. 
Maksoud, M.A.(2000). Response of growth and flowering of Manzanillo olive trees to different sources of nutrients. Egypt. J. Hort., 27: 513-523.

Mansour, A.E. and E.A. Shaaban (2007). Effect of different sources of mineral nitrogen applied with organic and biofertilizers on fruiting of Washington navel orange trees. J. Appl. Sci. Res., 3(8): 764-769.

Mansour, A.E.; F.F. Ahmed and Y.H. Ahmed (2004). Effect of bio and organic sources of $\mathrm{N}$ as a partial substitute for mineral fertilizer on fruiting of Sewy date palms. $2^{\text {nd }}$ Inter. Conf. on Date Palm Fac. of Agric., Suez Canal University, El Arish, Egypt.

Mohamed, M.A. and M.A. Ragab (2004). Response of Sewy date palms to application of some organic fertilizers. $2^{\text {nd }}$ Inter. Conf. on date Palm, Suez Canal Univ., El- Arish 6-8 October.

Mohammed, S.M.; T. A. Fayed; A.F. Esmail ; N. A. Abdou (2010) . Growth, nutrient status and yield of Le-Conte pear trees as influenced by some organic and biofertilizers rates compared with chemical fertilizer. Bull. Fac. Agric., Cairo Univ., 61 :17-32.

Morsi, M.E. (2009). Response of date palm "Sewy cv." grown in new reclaimed land to organic and inorganic nitrogen sources. Fayoum J. Agric. Res. and Dev., 33(1): 160-172.

Mostafa, R.A. (2008). Effect of bio and organic nitrogen fertilization and elemental sulphur application on growth, yield and fruit quality of Flame Seedless grape vines. Assiut J. of Agric. Sci., 39(1): 90-96.

Mouftah, R.T. (2007). Response of Taimour and Zebda mango trees to application of organic and biofertilization along with seaweed extract. Ph. D. Thesis, Fac. of Agric., Minia Univ., Egypt.

Moustafa, E.A. (2002). Effect of different nitrogen fertilizer distribution through the growth season on vegetative growth, yield and fruit quality of some banana cultivars. Assiut J. Agric. Sci., Egypt, 31(4): 231-245.

Moustafa, M.H. (2002). Studies on fertilization of Washington navel orange trees. Ph.D. Dissertation, Fac. of Agric., Moshtohor, Zagazig Univ. Benha Branch, Egypt.

Myint, C.C. (1999). EM Nature Farming Technology, Res. and Extension Activities in Myanmar. $6^{\text {th }}$ Inter. Conf. on Kyusei Nature Farming, Pretoria South Africa, 28-30 Oct.

Nijjar, G.S. (1985). Nutrition of Fruit Trees. Mrs Msha Raj Kumar for Kalyany Publishers, New Delhi pp. 10- 52.

Osman, S.M. and I.E. Abd El-Rhman (2010). Effect of organic and bio $\mathrm{N}$-fertilization on growth, productivity of fig tree (Ficus carica, L.). Res. J. Agric. \& Biol. Sci., 6 (3): 319-328. 
Roshdy, Kh. A. (2004). Effect of some organic nitrogen fertilizers on growth and fruiting of Williams banana. Ph. D. Thesis Fac. of Agric., Minia Univ., Egypt.

Russo, R.O. and G.P. Berlyn (1990). The use of organic biostimulants to help low-input sustainable agriculture. J. Sustain. Agric., 1(2):19-42.

Saad, R.L.; Kh. A. Roshdy and N. A. Abd El- Migeed (2011). Response of Zaghloul date palms grown under new reclaimed lands to application of organic and biofertilizers. Alex Exch. J., 31 (2): 121- 129.

Salama A.S. (2002). Response of some fruit species transplants and trees to organic fertilization. Ph.D. Thesis, Fac. Agric., Moshtohor, Zagazig Univ., Benha Branch, Egypt.

Sayed, E.F. (2008). Physiological studies on the behaviour of Saidy date palms under some treatments. Ph. D. Thesis, Fac. of Agric., Assiut Univ., Egypt.

Shaalan N. G. (2008). Response of Balady mandarin trees to application of some bio, organic, inorganic and slow release $\mathrm{N}$ fertilizers. Ph. D. Thesis, Fac. Agric., Minai Univ., Egypt.

Shaheen, M.A.; S. M. Abd El-Wahab; F.M. El-Morsy and A.S. Ahmed (2013). Effect of organic and bio-fertilizers as a partial substitute for NPK mineral fertilizer on vegetative growth, leaf mineral content, yield and fruit quality of Superior grape vine. J. Hort. Sci. \& Ornamen Plants, 5 (3): 151-159.

Shaheen, M.A.; M.M. Eissa and S.M. Mahmoud (2009). Influence of organic and biofertilization on growth, yield and fruit quality of Williams banana. J. Agric. Sci., Mansoura Univ., 34 (7): 8013-8025.

Sharawy , A.M. (2005). Response of Balady lime trees to organic and biofertilizers. Minia J. Agric. Res. and Develop., 25:1-18.

Snedecor, G.W. and W.G.Cochran (1991). Statistical Methods. Eight edition, Iowa State Univ. Press, Ames. pp 503.

Uwakiem, M. Kh. (2011). Effect of some organic, bio and slow release $\mathrm{N}$ fertilizers as well as some antioxidants on vegetative growth, yield and berries quality of Thompson Seedless grapevines. Ph.D. Thesis, Fac. Agric., Minia Univ., Egypt.

Wilde, S. A.; R. B. Corey; J. G. Lyer and G. K. Voiget (1985). Soil and Plant Analysis for Tree Culture. Oxford and IBH publishing Co., New Delhi, pp. 96 - 106. 


\title{
إستجابة أشجار المانجو صنف زبلدة للتسميد النيتروجينى العضوى التئي

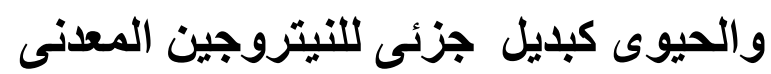

\author{
سعد ابراهيم حبشى (1) - مبشى \\ قسم بحوث الفاكهة الستو ائية ـ معهد بحوث البساتين- مركز البحوث الزر اعيةـ

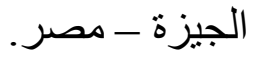

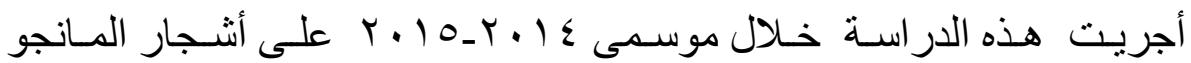

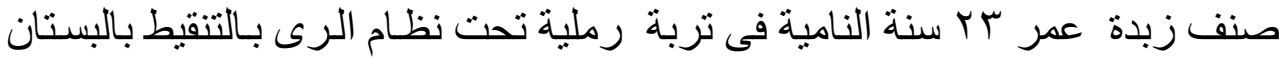

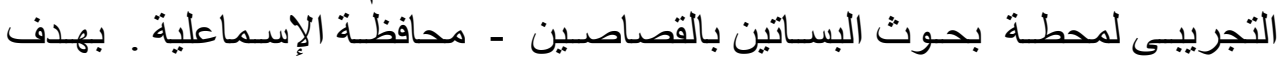

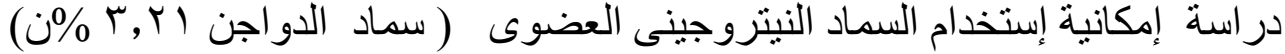
مع السماد الحيوى (البيوجين) كبديل جزئى للنيتروجين المعدنى ( سلفات الأمونيوم . $\%$ \% r.,

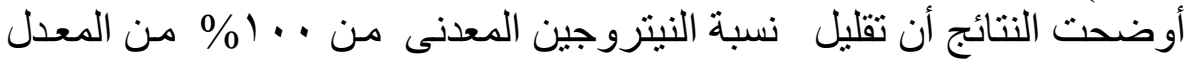

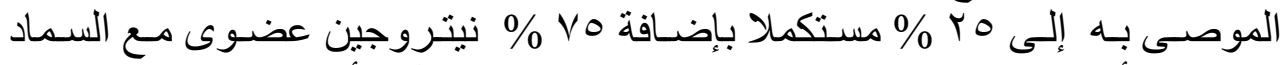

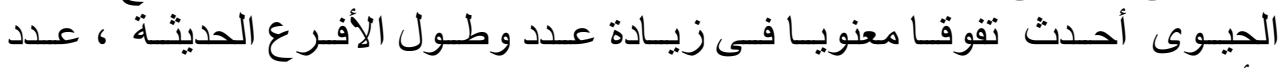

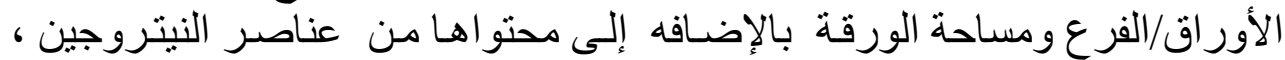

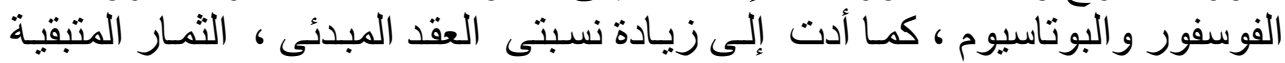

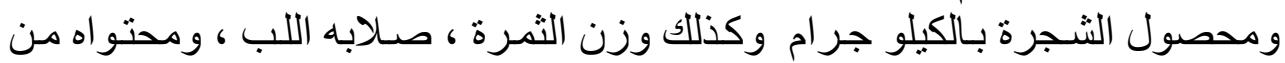

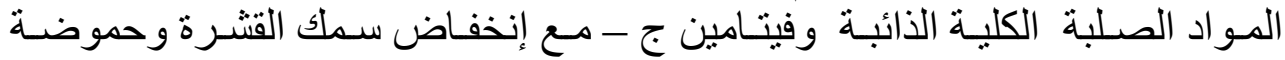

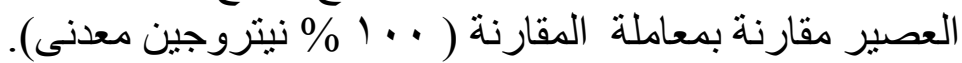

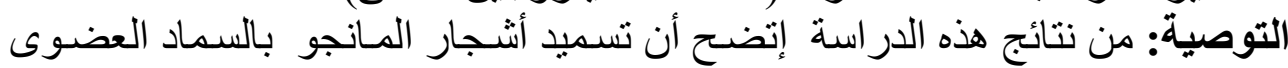

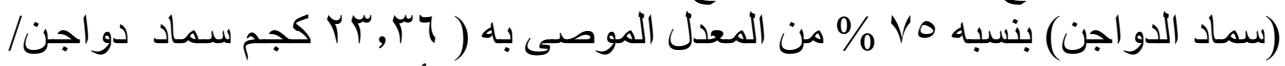

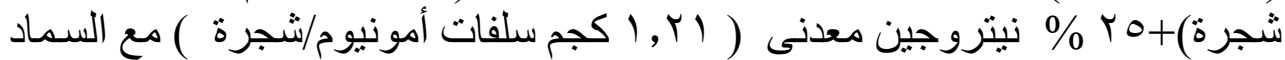

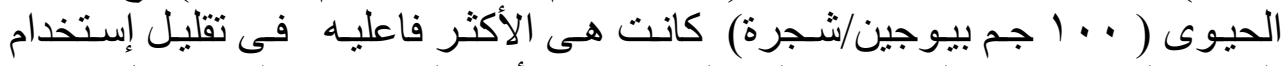

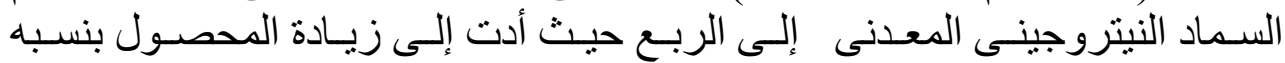

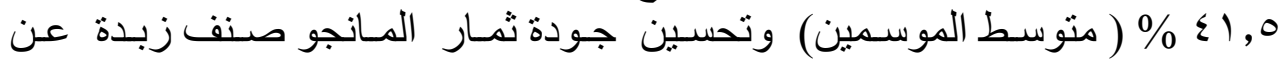
معاملة المقارنة . 